九州大学学術情報リポジトリ

Kyushu University Institutional Repository

\title{
Impact of Internet Penetration for the Economic Growth of Indonesia
}

Imansyah, Ryan

Interdisciplinary Graduate School of Engineering and Science, Kyushu University

https://doi.org/10.5109/1936215

出版情報 : Evergreen. 5 (2)，pp.36-43，2018-06. 九州大学グリーンアジア国際リーダー教育センター バージョン:

権利関係 : 


\title{
Impact of Internet Penetration for the Economic Growth of Indonesia
}

\author{
Ryan Imansyah,* \\ Interdisciplinary Graduate School of Engineering and Science, Kyushu University, Japan \\ *Author to whom correspondence should be addressed, \\ E-mail: 3ES15027K@s.kyushu-u.ac.jp
}

(Received February 28, 2018; accepted June 4, 2018).

\begin{abstract}
Broadband internet became a daily basis for the modern life. All activities especially business is going online. Therefore, the impact of broadband Internet on the economy is interesting to be studied especially its penetration. According to Akamai, the first quarterly report of 2016, the internet speeds for IPv4 connections average peak of Indonesia of 110.2 Mbps was ranked the third before South Korea. However, the average connection speed is still far below the South Korea that has $29 \mathrm{Mbps}$, which is only 4.5 Mbps. Even though it is quite low, the year over year improvement percentage of average peak connection is consistently increased from 495\% on Q4 2015 and 535\% on Q1 2016. From the statistics from Akamai, even though the super-fast internet connection is available in Indonesia, it is not evenly distributed throughout the country. However, this internet penetration will keep increasing as the project of the government to connect 57 cities in Indonesia will be finished at the end of 2018 .
\end{abstract}

Keywords: Internet penetration, gross domestic product, economy of Indonesia

\section{Internet penetration and economic growth}

Internet creates whole new industries and increases the opportunity by its ability to improve the innovation, spread knowledge, empower consumers, builds up network and organize social interactions over the globe [1]. Broadband internet became a daily basis for the modern life. All activities especially business is going on line. Therefore, the impact of broadband Internet on the economy is interesting to be studied especially its penetration. According to the economists, economic growth can be modeled as a function of capital, labor and technology [2]. Internet can be used as the technology variable for this model, completing the investment and employment as the variable for capital and labor, respectively. One way to measure the economic growth is by measuring the percent rate of increase of Gross Domestic Product (GDP). A study about internet penetration and its correlation to GDP has been done for Nordic countries [3]. It shows that the GDP growth was following the growth of Internet penetration with the mirrors of two or three years' delay. However, the internet penetration in Nordic countries is more that $80 \%$, which means that most of the people are getting used to the internet.

This paper is broken down as follows: the first section is the introduction how the internet can give a positive effect on the economic growth. The second section is the discussion of investigation result of 5 points that can explain the correlation between internet penetration and Gross Domestic Product in some developed countries and the case for Indonesia. The final section is the amplifications of the internet in Indonesia and policies to utilize the internet.

\section{Internet role for economic growth in Indonesia.}

It is obvious that the developed countries embraced the power of internet economy and experienced economic growth. Its representative is the United States. The study that was conducted by Professor John Quelch of Harvard Business School emphasized that Internet is used for online banking, news, weather, product websites, price comparisons, etc. He said that internet employs 1.2 million people directly to conduct advertising and commerce, build and maintain the infrastructure, and facilitate its use. Internet job supports approximately 1.54 times additional jobs elsewhere in the economy [4]. Internet produces $\$ 20$ billion in advertising, $\$ 85$ bilion in retail transactions, and $\$ 70$ billion to internet service providers in the United States [5]. Quelch also mentioned about the success of small businesses from the internet by saying that the internet helps the economy by fostering innovation, entrepreneurship, and productivity, particularly among small businesses that create most jobs in the US [4]. Internet as the core of information and 
communication technology (ICT) has proved positive contribution to the economic growth in every country [6]. It has proved that the proper infrastructure, ICT can be an enabler for socioeconomic development [7].

One of problems for the use of internet is privacy. Too much openness that can lead to the fraud. The Organization of Economic Cooperation and Development discussed about this matter with the leaders of member nations. The summary of the discussion said that, balancing openness and security becomes a double-edged sword, as both are essential to the success of the internet [5]. This topic lead into the discussion about policy-making principles for an open internet. Allowing the small and medium sized businesses to be more competitive in their industries. In addition, governments can also take the advantage to improve their services and provide insight to constituent into their responsibilities [5].

\section{Five points to explain the correlation between internet and Gross Domestic Product (GDP)}

There are six points that is used to analyze the correlation between internet and GDP in the Nordic countries by the team from Stetson University [3]. These points are penetration of internet and telephony, infrastructure and governmental support, reviewing the connectivity score card, comparison against the economist's E readiness rankings, network readiness in Nordic Region, and individual country readiness index analysis. However, only 5 points that I discussed for the case of Indonesia. Those points are; penetration of internet and telephony, infrastructure and governmental support, reviewing the connectivity scorecard, network readiness index (NRI), and Individual country network readiness index analysis.

\subsection{Penetration of Internet and Telephony}

Different from the developing country, Nordic Countries have some of the highest internet adoption and highest GDP levels per capita globally. In 2000 telephony still remains as primary method of communication, however, mobile cellular started to be above the telephone line subscription per 100 users. At this time, there is only 38 percent of citizen using the Internet. In 2010, mobile cellular subscriptions are growing fast into an average of 123 per 100 users with the internet use almost cover 91 percent of the population in that region.
Meanwhile, the telephone use has dramatically reduced to just over 44 percent [10]. On the other hand, the average of internet penetration over the world is only $30.5 \%$.

On the other hand, the last data in 2015, Indonesia only has $20.4 \%$ for the internet penetration. It makes the effect of Internet for the improvement of GDP for Indonesia and Nordic countries different.

In 2000, when the internet started to be used in wider

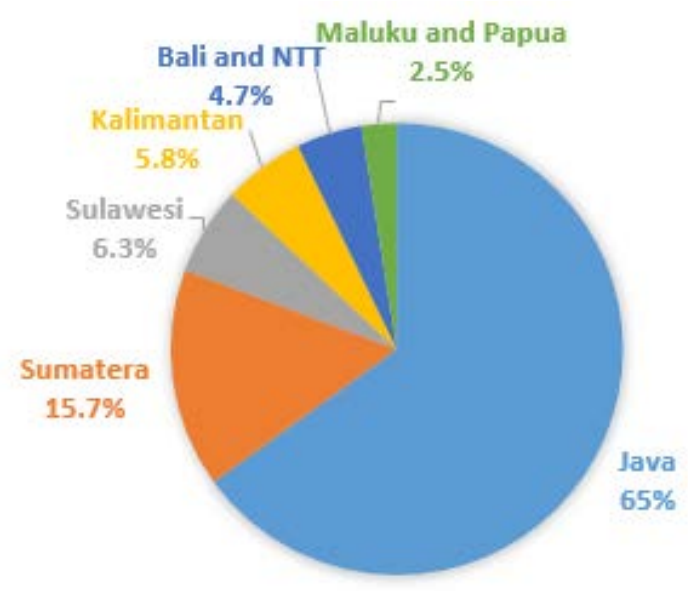

Fig. 1: Chart of the distribution of Internet penetration in Indonesia

society, the internet penetration in Indonesia is only $0.9 \%$ with 1,957,942 users from the total population of 211,540,428 people. According to APJII (Indonesia association internet services organizer) in 2016 the internet penetration already reached $51.8 \%$ with 132.7 million users from the population of 256.2 million people [12]. However, the distribution is uneven by islands. $65 \%$ of users are located in Java island, followed by $15.7 \%$ in Sumatera, 6.3\% in Sulawesi, 5.8\% in Kalimantan, $4.7 \%$ in Bali and Nusa tenggara timur, and 2.5\% in Maluku and Papua. The chart is shown in Fig. 1

Fig. 2 shows the composition of the internet user according to the age, $71.6 \%$ is working age (divided into $25-34,35-44,45-55)$, while $18.4 \%$ is students $(10-24)$, and $10 \%$ is elderly (more than 55 ). This percentage of working age user increased from 50.8\% from 2014. But the penetration according to the age, the working age has penetration of $49.2 \%$ (25-34 years old has $75.8 \%$, 35-44 years old has $54.7 \%$, and $45-54$ years old has $17.2 \%$ ), while the penetration of students is $75.5 \%$, and the elderly is $2 \%$. 


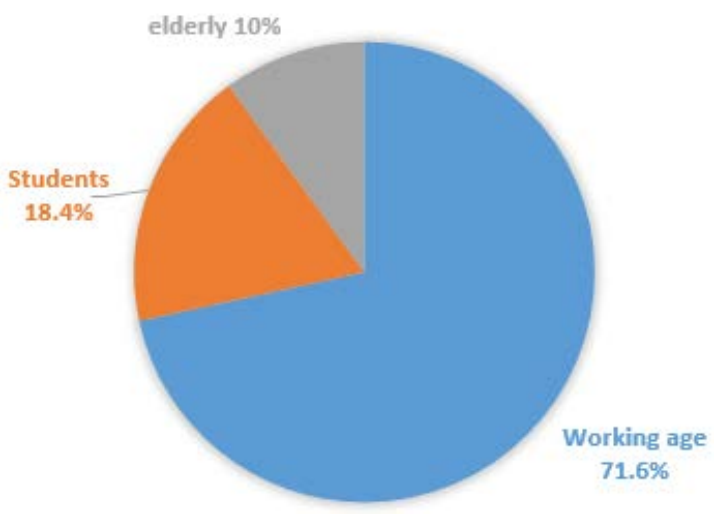

Fig. 2: Chart of the Internet penetration in Indonesia

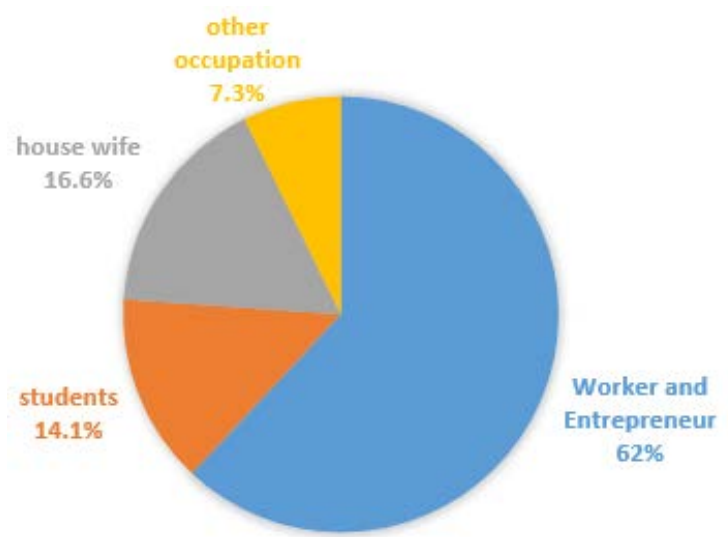

Fig. 3: Chart of the Internet penetration in Indonesia according to the occupation

Fig. 3 shows the chart of Internet penetration according to occupation, the composition of the user are $62 \%$ is worker or entrepreneur, $14.1 \%$ is students, $16.6 \%$ is house wife, and $7.3 \%$ is the other occupation. However, only $89.7 \%$ of the college students is using internet and $69.8 \%$ for school students, $58.4 \%$ for the worker, $25.3 \%$ for the house wife, and $6.7 \%$ for the other occupation [12].

\subsection{Infrastructure and Governmental Support}

Infrastructure is really important as the basis of internet penetration, as it is the fundamental needed to connect the people through the internet. Merriam-Webster defines infrastructure as the underlying foundation of the basic framework, and the system of public works of a country, state, or region. Generally, this infrastructure is falling into the private sector as the various entities each delivering data services via different types of technologies. However, in 2011 the ministry of enterprise, energy, and communication for Sweden published a report that states the central government has a responsibility, together with private actors, to ensure that communication services and the Internet work reliably and dependable.

In Indonesia, the internet is provided by the government and private sectors. There is only one provider belongs to the government, meanwhile, there are many private providers. Most of the people choose private provider due to the cost and the internet speed. However, the government is working on the project to make the fiber optic area range is wider. It will connect 57 cities in Indonesia. They divide it into 3 parts, west, middle, and east area. The west area will cover Riau and Riau islands that will be connected with $2000 \mathrm{~km}$ fiber optic. While the middle area will cover Kalimantan, Sulawesi, and North Maluku with the total fiber optic of $2700 \mathrm{~km}$. On the other hand, the east area will cover East Nusa Tenggara, Maluku, West Papua, and Papua. This area will need the total fiber optic of $6300 \mathrm{~km}$. This project will finish at the end of 2018, and hopefully, on 1st January 2019, this Palapa ring can be used effectively.

\subsection{Reviewing the connectivity scorecard}

Connectivity Scorecard is an annual study of international ICT infrastructure by Berkeley Research Group. They are focusing on 52 countries that have been divided into two scorecard groupings according to their economy type that has been defined by the World Economy Forum. The first one is resource-driven economies. This type of countries sometimes face barriers to attaining a widespread connectivity infrastructure in geographical or policy form. The challenge is this kind of economy is having a marketplace not suited to foreign investors and a shortfall in the Human Capital. These two are needed to make the using of the available infrastructure and thus increase the connectivity. On the other hand, Innovation-driven economies are more highly developed than resource and efficiency-driven economies. Basic connectivity infrastructure is usually available with a good base level of penetration and subscription. The challenges these economies face often lie in driving implementation of the latest technologies and uptake by the marketplace in order to increase connectivity.

There are 6 scorecard component to decide the connectivity scorecard; consumer infrastructure, consumer usage and skills, business infrastructure, business usage and skills, government infrastructure, and government usage and skills. 


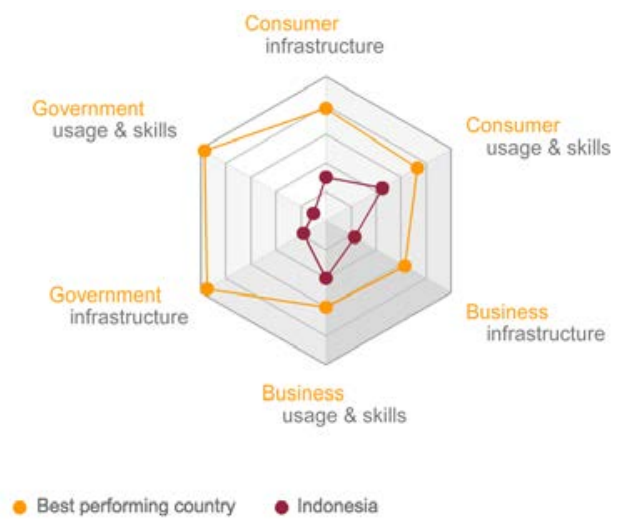

Fig. 4: Connectivity Performance by Scorecard Component of Indonesia [8].

The connectivity scorecard in 2011 for the Nordic countries was as follows; Sweden was the top with a score of 7.84, followed by Denmark with 7.47, while Norway ranked fifth with 7.09, and Finland ranked ninth with a score of 6.78. On the other hand, Iceland was not one of the fifty countries included in the connectivity score analysis because of its small size economy [3]. Thus to investigate the ICT penetration and its relation to GDP per capita of Indonesia, analysis of the connectivity scorecard is important. The value of connectivity scorecard was 2.89 on 2013 for Indonesia categorized as the type of resource-driven economic country. The details of components of the score are shown in Fig 4.

Indonesia has many types of internet connectivity that can be used by the customer. The first one is dial-up that is used since 1994 in Indonesia, however, this internet connectivity is not used anymore since the maximum speed is only $56 \mathrm{kbps}$. The second one is Asymmetric Digital Subscriber Line (ADSL), the advantage of this connectivity is giving high-speed internet connectivity and voice or fax simultaneously. The third one is general packet radio service (GPRS) that has the connectivity speed between $56 \mathrm{kbps}$ and 115 kbps. This internet connectivity has the largest coverage area for mobile phone, however, the coverage outside Java island is only in some big city. The third one is 3G, the connectivity speed of $3 G$ is higher than GPRS with the speed between $144 \mathrm{kbps}$ and $2 \mathrm{Mbps}$, depends on the condition of the user. However, the coverage area of this $3 \mathrm{G}$ is smaller than GPRS. The forth is Wireless LAN that uses radio wave. This connectivity can be used for peer to peer indoor and point to point for outdoor. This connectivity can solve the geography problem where the installation of the cable is hard. The speed of this connectivity already reaches $54 \mathrm{Mbps}$ with the frequency of $2.4 \mathrm{GHz}$. The last one is $4 \mathrm{G}$ LTE that is used for internet mobile connection. The speed of connectivity can reach 72 Mbps.

From the connectivity scorecard, the usage and skills for the business of Internet in Indonesia are not the worst Most of the internet user use the social media to do the business. They choose the social media such as facebook, twitter, Instagram, and so on because it can be accessed easily and free. According to APJII 2016, 97.4\% (129.2 million people) of internet users in Indonesia use the social media. However, the risk of doing a transaction by social media is really high since because there is no guarantor for the transaction like in Amazon or e-Bay. In Indonesia, the using of credit card is not as high as in the developed country. The transaction is done by using bank transfer according to the agreement between the seller and consumer. The fraud is not only from the distributor or seller but sometimes it comes from the consumer. To avoid this kind of fraud, local trading social media appeared. They facilitate the transaction between seller and consumer so that both of them can be protected from any fraud. The other effect of online trading is the high demand of the delivery system. Now in Indonesia, the number of the delivery company is increasing, within the city or between the city.

The other usage and skills for the business that is increasing in Indonesia is the online taxi. One of the biggest problem in Indonesia, especially in the big city like Jakarta, Bandung, Jogjakarta, and Surabaya, is the public transportation. The train line is not developed yet in Indonesia. People are using smaller mass transportation like bus, minibus, and bike taxi. However, many people are complaining about the comfort of using such kind of transportation. First, they need to find those public transportations by themselves, the price is not fixed, and they need to change so many public transportations for the longer destination. As the result, many people are using their own vehicle to be mobile. It makes the condition of traffic become worse. And then, many people are also getting tired to drive their own vehicle. From this situation, a group of people was making a company of online bike taxi where the consumer can ask the place to pick up and also they can get an information on the price beforehand to their destination. Many people are enthusiasts with this kind of public transportation. The demand was increasing day by day, and the company got so many suggestions to develop their business. Now, this company extends the business into some different business such as online taxi, online delivery taxi, online food delivery system, even we can ask a hairdresser, cleaner, and spa therapist to come to our home. This kind of system is really needed by the people who cannot leave their home but also need to fulfill some of their need.

\subsection{Network readiness Index (NRI)}

Annually, the world economic forum has published The Global Information Technology Report that also defines the network readiness of 138 countries [9]. The NRI can help to assess countries' ability to capitalize on the digital revolution and their preparedness to benefit 
from the emerging Fourth Industrial Revolution [8]. As we move into the digital era, levels of a country's network readiness will play a vastly more significant role in their competitiveness in the global environment, ultimately driving GDP levels. Networked readiness depends on the drivers necessary for digital technologies to unleash their potential in each country. These drivers are grouped into four subindexes, which are: the environmental subindex as first and second pillars; composed of political and regulatory environment, and business and innovation environment: the readiness subindex as third, fourth and fifth pillars; composed of infrastructure, affordability, and skills: usage subindex as sixth, seventh, and eight pillars; which is comprised individual usage, business usage, and government usage. While the impact is measured as separate subindex as ninth and tenth pillars, which is composed of economic impacts and social impacts.

Almost the same with connectivity scorecard in 2011, Sweden was in the first rank with a score of 5.6, followed by Finland in third place with 5.43, Denmark in seventh with 5.29, Norway in ninth with 5.21, and Iceland in sixteenth with 5.07. However, the Asian tigers, Hong Kong, Korea, Singapore, and Taiwan, gain and now head-to-head with the Nordic countries.

According to World Economy Forum in 2016, Indonesia moves up into 73rd place from 79th in the previous year. The overall score for the NRI is 4.0 according to the 10 pillars. From this 10 pillars, Indonesia has a good score in Affordability of 5.9 and skills of 5.1. Meanwhile, for Korea, they improve their last score but moves down 1 spot to 13 th place with a total score of 5.6. Almost all of the 10 pillar has a point more than 5, moreover, they have the best score in infrastructure and digital content index.

\subsection{Individual country network readiness index analysis}

There is a lot of variables that are affecting the network readiness index in a country. For example, in Nordic countries, Denmark first position in 2007 to 2009 dropped to third place in 2010 and finally seventh in 2011 because of the decrease of its tax rate from 2009 to 2010. Finland improved its position to third place in 2011 because of their availability of scientists and engineers, and cellular subscriptions with data \% total. They also had high rankings in venture capital availability, intellectual property protection, and property rights.

For the Iceland, despite of its low ranking, there is some improvement on the other areas, such as secure internet servers/million population, electricity production, accessibility of digital content, household with personal computer, internet users/100 population, internet access in school, use of virtual social networks, and firm-level technology absorption. The other top achievements of
Iceland are the availability of latest technologies and quality of educational system. There are only two areas with a low rank in Iceland, financial market sophistication, and government e-participation.

Norway that is always consistent ranked ninth in 2010 and 2011 did place high in many areas, such as; venture capital availability, electricity production, internet users/ 100 population, freedom of the press, the extent of staff training, and impact of ICT on new organizational models that have important impact on its economy. Not like the others Nordic countries, Norway did not have any low-ranked variables.

Lastly, Sweden that always in the top two ranked in 2007 to 2011, ranked first globally in the variables of availability of latest technologies, laws relating to ICT, efficiency of legal system in challenging regulations, intellectual property protection, company spending on $R \& D$, impact of ICT on access to basic services, extent of business internet use, impact of ICT on new services and products, and impact of ICT on new organizational models. However, Sweden also has a low rank in extent and effect of taxation, and total tax rate, \% of profits.

From this example, an analysis of these variables is important to see how is the improvement of Indonesia's NRI score. The first pillar of NRI is the political and regulatory environment. Overall, the rank of this pillar is not really bad, however, Indonesia got a bad rank, which is 94 from 139 countries for its software piracy rate with the percentage of $84 \%$. Indonesia got a really bad rank for the time to start a business and number of procedures to start a business which is 47.8 days and 13 number of procedures, respectively. Indonesia also doesn't perform well for the 3rd pillar which is the infrastructure and digital content, the electricity production of Indonesia has placed the rank of 100 from 139 countries with only $858 \mathrm{kWh} /$ capita. While the international internet bandwidth is ranked 112 with only $6.2 \mathrm{~kb} / \mathrm{s} / \mathrm{user}$ and secure internet servers is placed 103 in the rank with 6.2 servers / million population. Despite that bad rank, Indonesia has a good rank for the affordability pillar as the 4th pillar, Indonesia has a low tariff for its mobile cellular and fixed the broadband internet, 0.2 PPP \$/minute and 27.9 PPP \$/month respectively. For the 5th pillar which is skill, Indonesia only got a bad rank in the secondary education enrollment rate, with the rank of 91 and 82.5 gross \%. In fact, the unemployment rate is the worse from the people who don't get the secondary education, with the percentage of $60 \%$. In the 6th pillar which is individual usage, Indonesia has a low percentage of fixed-broadband internet subscriptions with only $1.2 \%$ of the population. Meanwhile, the people use of virtual social networks is placed the rank of 36. It shows that despite the low penetration of Internet, most of the internet user actively using the application of the social network. For the 7th pillar, business usage, Indonesia has a good rank for the internet use for biz-to-consumer transactions. The rank is 
28 with the score of 5.4 from the maximum score of 7. People use any social application and website to sell their products. Government usage as 8th pillar has the rank of 65, pretty much Indonesia doesn't have enough government online services, however, the government is improving their services through online. In the 9th pillar, which is economic impacts, Indonesia was in the 85 number, however, the people think that the ICT has a great impact for new service and products, and also new organizational models. The 10th pillar, which is social impacts, Indonesia has a good score for the impact of ICTs on access to basic services, internet access in schools, and ICT use and government efficiency, however, the E-participation index score is pretty low with the score of 0.3 from 1 . E participation shows the quality, relevance, and usefulness of government websites in providing online information and participatory tools and services to their citizens.

\subsection{Gross Domestic Product}

Based on the hypothesis that higher levels of internet penetration drive higher GDP growth, it would be assumed that GDP per capita of Nordic countries would show the highest levels in the world. According to World Bank, all five of the countries were ranked as the top 20 in 2011. Figure 2 shows the level of correlation exists between GDP level and Internet usage. It shows clearly that countries with the highest internet penetration have the highest GDP and vice versa. However, it only demonstrates correlation and not causality.

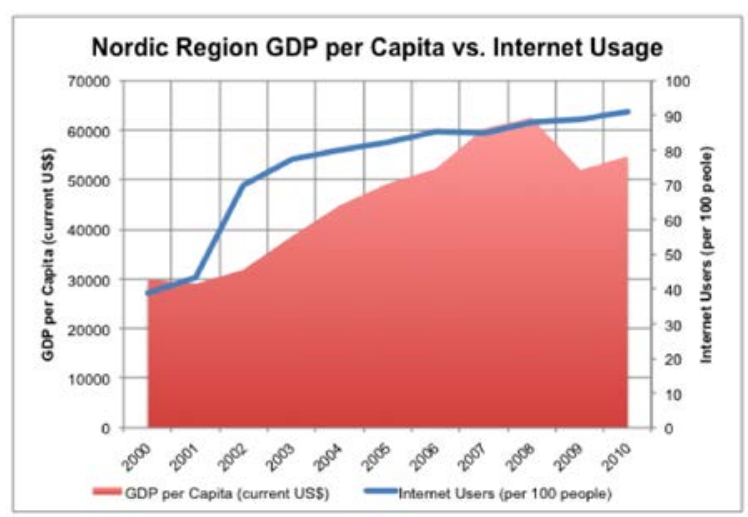

Fig. 5: Nordic Region GDP per Capita and the internet usage based on World bank data in 2011. [3]

Figure 5 shows the data of internet users and GDP per capita over a series of time. From this graph, between 2000 and 2010, the internet penetration grew in early 2000 with a very fast rate. About two years after the initial spike of internet penetration growth, GDP levels start to rise. The growth of GDP nearly mirrors of the internet penetration curve at a two or three years' delay.

To analyze the effect of the Internet in Indonesia, a comparison between internet penetration and GDP is needed. In Nordic countries, Internet penetration is already more than $50 \%$, it might be affecting the GDP since many people use the internet for their daily activity. However, for Indonesia, in 2015 itself, the internet penetration only hit $36.5 \%$. Thus, the effect of the Internet on Indonesia's GDP should be analyzed more.

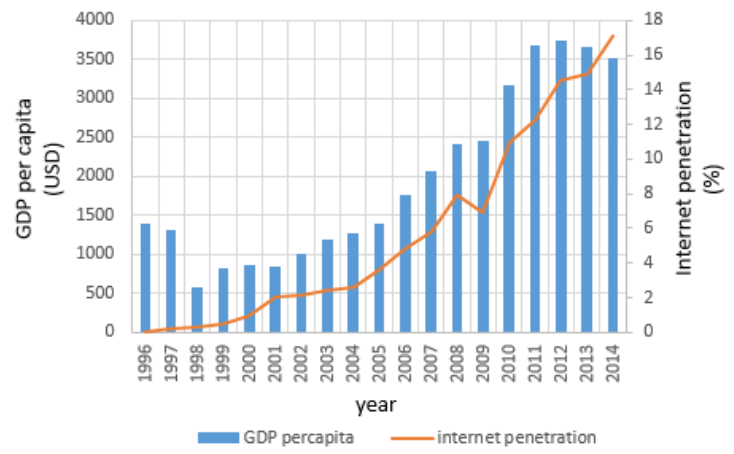

Fig. 6: GDP per capita and internet penetration in Indonesia as a function of time.

The Gross Domestic Product (GDP) in Indonesia was worth 861.93 billion US dollars in 2015. The GDP value of Indonesia represents 1.39 percent of the world economy. GDP in Indonesia averaged 228.00 USD Billion from 1967 until 2015, reaching an all-time high of 917.87 USD Billion in 2012 and a record low of 5.98 USD Billion in 1967. Figure 6 shows the data of GDP per capita [13] and the internet penetration [10] of Indonesia from 1996 to 2014. Different from the Nordic countries, mirrors condition between GDP per capita and the internet penetration. In contrast, the internet penetration looks following the increase of GDP per capita even though in 2010 when the GDP was decreasing, the internet penetration was increased. Start from 2010, the internet was used for many things especially to help the daily activity of the people. Many successful startup companies were born at this time. For example, the first startup company is Tokopedia, it is an online shopping website that was founded in 2009. Tokopedia is the first internet company in southeast Asia that succeeded to close US\$100 million in funding from Softbank and Sequoia Capital. It is known that Softbank is the investor behind the success of Alibaba [14]. The second startup that has a big impact on the decreasing of the unemployment rate in Indonesia is Go-Jek. Go-Jek was established on 2010 as a motorcycle ride-hailing phone service. Now the business is developed into services for transportation, logistic, mobile payments, food delivery, and other on-demand services [15]. The people who join this startup company to give their services to the consumer is called partners. $56 \%$ to $85 \%$ of the partners are the holder of junior high school and high school certificate only, which is the highest rate of 
unemployed people in Indonesia which is $60 \%$ of the total unemployed [16]. Figure 7 shows the data of unemployed percentage and internet penetration in Indonesia.

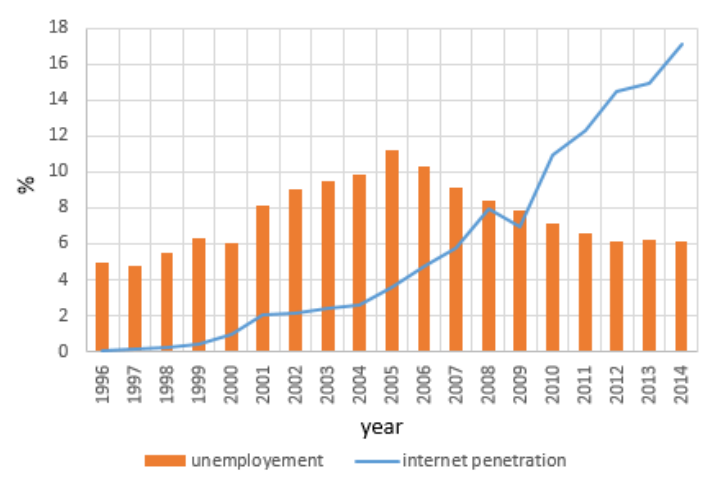

Fig. 7: Nordic Region GDP per Capita and the internet usage based on World bank data in 2011. [3]

\section{Conclusion}

According to Akamai first quarterly report of 2016 that examines global internet speeds for IPv4 connections, Indonesia with the average peak of 110.2 Mbps ranked third before South Korea which has the average peak of 103.6 Mbps [11]. However, the average connection speed is still far below the South Korea that has $29 \mathrm{Mbps}$. The average connection speed of Indonesia is only 4.5 Mbps. Even though it is quite low, the year over year improvement percentage of average peak connection is consistently increased from $495 \%$ on Q4 2015 and 535\% on Q1 2016, and it is believed that it still growing.

From the statistics from Akamai, we can get that even though the super-fast internet connection is available in Indonesia, it is not evenly distributed throughout the country. However, according to Indonesia Association of Internet Service Providers (APJII), which is the association of Internet services organizer reported that the infrastructure development all over Indonesia is increasing since the beginning of 2016. In Java, the development already reaches $70 \%$, while Sumatra is $60 \%$. The most difficult location is Papua. The eastern part of Indonesia such as Papua and Maluku are expected can be helped after the project of Palapa Ring finish.

To maximize the existent of the internet for the GDP of Indonesia, the regulation of Internet still needs to be improved, how well organize the internet for business. Many sellers use common social media, the buyer needs to transfer some money to the seller before they get the goods from the seller. In this case, some seller does a fraud after they receive the money they just run away and does not send the goods. On the other case, they send the goods that are not the same quality with the description on the internet. For this case, there is no third party that can guarantee the customer and also the seller for their transaction. Transaction safety will increase the trust of people to do the business through the internet.

In conclusion, probably so far the internet penetration in Indonesia is not much affecting the economy of Indonesia because the internet penetration is not equally distributed in all the cities in Indonesia. It is concentrated inside Java island especially Jakarta. However, this internet penetration will keep increasing as the project of the government to connect 57 cities in Indonesia finish at the end of 2018.

\section{Acknowledgements}

I would like to thank Green Asia for the extraordinary support in this paper.

\section{References}

1) S. Y. Chu, "Internet, Economic Growth and Recession,” Modern Economy, Vol. 4, 209-213, 2013.

2) Barro and Sali-i-Marting, Economic growth, MIT Press, 2004.

3) S. Amiri and B. Reif, "Internet Penetration and its Correlation to Gross Domestic Product: An Analysis of the Nordic Countries," International Journal of Business, Humanities and Technology, Vol 3, No. 2, 50-60, 2013.

4) Quelch. J, "Quantifying the economic impact of the internet," Harvard Business School Working Knowledge, 17 August, 2009.

5) Meah. M, "The impact of internet on economic growth in Bangladesh,” City University of New York (CUNY) master's theses, 2012.

6) Setiadi. F, "An overview of the development Indonesia national cyber security,” International Journal of Information Technology and Computer Science, Vol. 6, December, 2012.

7) S. Kamel, D. Rateb, and M. El-Tawil, "The Impact Of ICT InvestmentsOn Economic Development In Egypt,” Electronic Journal on Information Systems in Developing Countries, vol. 36, no. 1, pp. 1-21, 2009.

8) Rajala consulting report for connectivity scorecard in 2013 :

http://www.connectivityscorecard.org/ [accessed 13.11.2017] 
9) World Economic Forum (2010). The Global Competitiveness Report 2010-2011. (K. Schwab, Ed.) Retrieved April 2, 2012, from World Economic Forum: http://www3.weforum.org/docs/WEF_Glob alCompetitivenessReport_2010-11.pdf [accessed 13.11.2017]

10) World Bank. (2011). World Develolpment Indicators \& Global Development Finance. Retrieved March 31, 2012, from World dataBank: http://databank.worldbank.org/ddp/home. do?Step $=12 \& i d=4 \& C N O=2$ [accessed 13.11.2017]

11) Akamai connectivity report in 2016 :

https://content.akamai.com/PG6575-q1-2016-soti-co nnectivity-report.html [Accessed 17.01.2018]

12) APJII (Indonesia association internet services organizer) report on 2016.

13) International Monetary Fund data bank : http://www.imf.org/external/datamapper/N GDPDPC@WEO/IDN [accessed 17.01.2018]

14) https://www.tokopedia.com/about [accessed 17.01.2018]

15) https://www.go-jek.com/about/ [accessed 17.01.2018]

16) Communication Study Center Universitas Indonesia (PUSKAKOM) :

http://puskakom.ui.ac.id/publikasi/hasil-riset-manfaa t-sosial-aplikasi-on-demand-studi-kasus-gojek-indo nesia.html [accessed 17.01.2018] 